\title{
The correlates of benefit from neoadjuvant chemotherapy before surgery in non-small-cell lung cancer: a metaregression analysis
}

Hakan Bozcuk ${ }^{*}$, Huseyin Abali and Senol Coskun ${ }^{1}$ On behalf of the Lung Cancer Committee of Turkish Oncology Group

\begin{abstract}
Background: Although neoadjuvant chemotherapy (NCT) is widely used, it is not clear which subgroup of locally advanced non-small-cell lung cancer (NSCLC) patients should be treated with this approach, and if a particular benefit associated with NCT exists. In this study, we aimed to investigate the potential correlates of benefit from NCT in patients with NSCLC.

Methods: All randomized clinical trials (RCTs) utilizing a NCT arm (without radiotherapy) versus a control arm before surgery were included for metaregression analysis. All regression analyses were weighed for trial size. Separate analyses were conducted for trials recruiting patients with different stages of disease. Previously published measures of treatment efficacy were used for the purpose of this study, regardless of being published in full text or abstract form.

Results: A total of 14 RCTs, consisting of 3,615 patients, were selected. Histology, stage, various characteristics of the NCT protocol, and different trial features including trial quality score were not associated with the benefit of NCT. However, in trials of stage 3 disease only, there was a greater benefit in terms of reduction in mortality from $\mathrm{NCT}$, if protocols with three chemotherapeutics were used $(B=-0.18, t=-5.25, P=0.006)$.

Conclusions: We think that patients with stage 3 NSCLC are served better with NCT before surgery if protocols with three chemotherapy agents or equally effective combinations are used. In addition, the effect of neoadjuvant chemotherapy is consistent with regard to disease and patient characteristics. This finding should be tested in future RCTs or individual patient data meta-analyses.
\end{abstract}

Keywords: Meta-analysis, Metaregression, Mortality, Neoadjuvant chemotherapy, Non-small-cell lung cancer

\section{Background}

Locally advanced cases of non-small-cell lung cancer (NSCLC) constitute nearly a fifth of all NSCLC cases $[1,2]$. Different standards exist for the treatment of locally advanced NSCLC, partially owing to the heterogeneous nature of this disease, and lack of consistent data regarding treatment outcomes [2,3].

Although chemoradiotherapy and neoadjuvant chemotherapy (NCT) followed by surgery are two widely utilized therapeutic approaches, NCT is still considered as

\footnotetext{
* Correspondence: hbozcuk@gmail.com

${ }^{1}$ Akdeniz University Hospital, Dept. of Medical Oncology, Antalya, Turkey

Full list of author information is available at the end of the article
}

experimental, primarily because previous meta-analyses have been inconclusive [2-7]. The last meta-analysis in particular shows the benefit of NCT, but fails to point out any special feature that is linked with the magnitude of efficacy of NCT [8]. Therefore, from a practical point of view, the important questions of which patients should be treated with NCT, and whether there is any superior type of NCT, still remain to be solved.

Related to these uncertainties regarding NCT, we aimed to formulate hypotheses by looking into various factors in previous randomized controlled trials (RCTs) of NSCLC, which could be linked with the magnitude of benefit from NCT, and thus, decided to conduct a metaregression analysis to explore these factors. 


\section{Materials and methods Inclusion and exclusion of trials}

All RCTs reported after 1966 with an NCT arm versus a control arm (no NCT arm) before surgery were included in this analysis. Two reviewers (HB, HA) selected RCTs and extracted the data. All stages and full text or abstract formats in English language literature only were allowed. References of key articles were also referred to. Hazard ratio (HR) was selected as summary data for treatment efficiency for mortality, and used as given in the last full text meta-analysis [7], or in the original publication of trials.

Non-randomized trials, as well as those with the inclusion of radiotherapy before surgery (that is, induction chemoradiotherapy trials) were excluded from the analysis.

\section{Metaregression analysis}

Hazard ratios for mortality for individual trials were log transformed prior to being used as independent variables in the linear regression analysis. All analyses were weighed for the square root of individual trial size, as a conservative measure of the (trial size adjusted) effect of individual RCTs. However, for exploratory purposes, we also tested the effect of trial size on the magnitude of the associated hazard ratio of individual RCTs, and in these analyses only, weighting for the square root of trial size was not carried out. All trials, and also those with stage 3 only, and mixed stage trials (stage 1 to 3 ), were separately analyzed. A $P$ value $<0.05$ was considered to be significant.

A trial quality score was constructed using a scale from 0 to 3, depending on three features; randomization method (details given vs not given), stratification criteria (reported vs not reported), and trial type (reported in full text or abstract). So, 0 or 1 point for each trial feature was totaled for the final trial quality score. We also drew simple regression lines to illustrate the relationship between mortality and its predictors in clinically significant subgroups as shown in the literature [9].

\section{Results}

A total of 3,615 patients were represented in 14 RCTs [10-26]. The median number of cases in each trial was 240.5 (26 to 624). Publication years varied between 1990 and 2010, and the median fraction of patients with squamous cell cancer was $51.5 \%$. A median of three cycles of NCT (1 to 3) was used and the median trial quality score was 1 (0 to 3$)$. Six of the trials (42.9\% of all trials) addressed patients with stage 3 only disease, whereas eight trials (57.1\%) included patients with mixed stage (1 to 3 ) NSCLC. See Table 1 for individual RCT characteristics.
None of the factors evaluated in the regression analysis were linked with the efficacy of NCT. These factors were histology, stage, type of platinum drug used, generation and number of drugs in the protocol, number of cycles administered before surgery, trial size, publication year, origin of study and trial quality score. Only stage of disease interacted with the number of chemotherapy drugs used to define the magnitude of NCT benefit. In stage 3 patients, reduced risk of mortality was associated with the utilization of more frequent usage of three drug regimes $(\mathrm{B}=-0.18, \mathrm{t}=-5.25, P=0.006)$. Table 2 shows details of the regression analysis. The $\mathrm{R}^{2}$ value for the association of log transformed hazard ratios for mortality with number of drugs in the protocol was 0.92 in trials of stage 3 disease, and 0.27 in trials of mixed stages (stages 1 to 3 ).

When only trials recruiting solely stage 3 patients were considered, patients who received three drugs obtained a $35 \%$ reduction in hazard ratio for mortality compared to those that received two to three drugs (hazard ratio = 0.53 in three drug trials, versus 0.81 in two to three drug, heterogeneous treatment design trials). In the only trial utilizing two drugs, neoadjuvant chemotherapy was associated with a 19\% increased risk of mortality over no neoadjuvant chemotherapy (hazard ratio $=1.19$ ).

The association with NCT benefit of protocols with two or three chemotherapeutics in stage 3 or other stages is represented in Figure 1 . As only a minority of the trials reported data on the toxicity of NCT, we did not conduct a separate analysis to define correlates of toxicity.

\section{Discussion}

We show for the first time that if NCT is to be used, a higher number of chemotherapy drugs in the treatment protocol may be associated with decreased mortality in stage 3 NSCLC. However, in contrast, the most recent individual patient data (IPD) meta-analysis failed to demonstrate any factor that was associated with NCT benefit in NSCLC [8]. It would be worthwhile to test the validity of our hypothesis in this IPD meta-analysis dataset. Of note, in the literature, a large NCT RCT with three drug protocols containing third-generation agents with at least three cycles of treatment and conducted solely in stage 3 NSCLC patients is lacking. To have such a RCT would obviously provide great insight into the current management of stage 3 disease in NSCLC.

Third-generation three-drug protocols have previously been tried in small trials in the setting of stage 3 NSCLC $[27,28]$. Gemcitabine, vinorelbine, cisplatin (GVP) particularly, appear to be promising among these regimens, with a pathological complete response rate of $25 \%$ [27]. Therefore, future RCTs using these three-drug protocols for NCT are warranted. In addition, proper staging in 
Table 1 Characteristics, methodological quality, treatment employed and outcome of the trials

\begin{tabular}{|c|c|c|c|c|c|c|c|c|c|c|c|c|}
\hline Trial & Reference & $\begin{array}{l}\text { Recruitment } \\
\text { period }\end{array}$ & $\begin{array}{l}\text { Publication } \\
\text { year }\end{array}$ & $\begin{array}{l}\text { Trial } \\
\text { size }\end{array}$ & $\begin{array}{l}\text { Origin of } \\
\text { study }\end{array}$ & $\begin{array}{l}\text { Randomization } \\
\text { method }\end{array}$ & $\begin{array}{l}\text { Stratification } \\
\text { criteria }\end{array}$ & Trial type & Stage & $\begin{array}{l}\text { Fraction with } \\
\text { squamous } \\
\text { cell (\%) }\end{array}$ & $\begin{array}{l}\text { Details of } \\
\text { neoadjuvant } \\
\text { treatment }\end{array}$ & $\mathrm{HR}^{\mathrm{a}}(95 \% \mathrm{Cl})$ \\
\hline Dautzenberg et al. & 10 & 1985 to 1987 & 1990 & 26 & European & No details given & Not reported & Full text & Stage 1 to 3 & 81 & $\mathrm{VCP} \times 2$ & 1.10 (0.41 to 2.93 ) \\
\hline Roth et al. & 13,14 & 1987 to 1993 & 1998 & 60 & US & No details given & Not reported & Full text & Stage 3 only & 37 & CEP $\times 3$ & 0.56 (0.31 to 1.01$)$ \\
\hline Rosell et al. & 11,12 & 1989 to 1991 & 1999 & 60 & European & Details given & Not reported & Full text & Stage 3 only & 70 & $\mathrm{MIP} \times 3$ & 0.50 (0.30 to 0.85 ) \\
\hline Zhou et al. & 21 & 1990 to 2001 & 2001 & 624 & Asian & Details given & Not reported & Full text & Stage 3 only & 51 & $\begin{array}{l}\mathrm{BAl} / \mathrm{MVP} / \mathrm{CAP} / \mathrm{EP} / \\
\mathrm{VIP} / \mathrm{GP} / \mathrm{NP} / \mathrm{PC} / \mathrm{TN} \times 2\end{array}$ & 0.87 (0.71 to 1.07 ) \\
\hline De Pierre et al. & 15 & 1991 to 1997 & 2002 & 355 & European & No details given & Reported & Full text & Stage 1 to 3 & 74 & MIP $\times 2$ & 0.83 (0.64 to 1.07 ) \\
\hline JCOG & 16 & 1993 to 1998 & 2003 & 62 & Asian & No details given & Reported & Full text & Stage 3 only & 24 & $V P \times 3$ & 1.19 (0.69 to 2.05 ) \\
\hline Li et al. & 24 & 1990 to 1995 & 2003 & 137 & Asian & No details given & Not reported & Full text & Stage 3 only & 80 & CAP/EP $\times 1$ & 0.68 (0.46 to 1.00$)$ \\
\hline Liao et al. & 22 & 1995 to 1997 & 2003 & 211 & Asian & Details given & Reported & Full text & Stage 1 to 3 & - & MVP/MAP $\times 2$ & 1.06 (0.76 to 1.48$)$ \\
\hline Yao et al. & 23 & 1990 to 2002 & 2004 & 456 & Asian & Details given & Not reported & Full text & Stage 3 only & 55 & $\begin{array}{l}\text { GP/NP/MVP/ } \\
E P \times 2\end{array}$ & 0.83 (0.67 to 1.03 ) \\
\hline Sorensen et al. & 17 & 1998 to 2004 & 2005 & 90 & US & No details given & Not reported & Abstract & Stage 1 to 3 & - & $\mathrm{TP} \times 3$ & 0.91 (0.55 to 1.50$)$ \\
\hline s9900 & 18,19 & 1999 to 2004 & 2006 & 336 & European & No details given & Not reported & Full text & Stage 1 to 3 & 38 & $P C \times 3$ & 0.79 (0.60 to 1.06$)$ \\
\hline MRCLU22 & 6 & 1997 to 2005 & 2007 & 519 & European & No details given & Not reported & Full text & Stage 1 to 3 & 49 & $\begin{array}{l}\text { MVP/MIP/NP/ } \\
\mathrm{PC/DC/GP \times 3}\end{array}$ & 1.02 (0.80 to 1.31$)$ \\
\hline Ch.E.S.T & 20,25 & 2000 to 2004 & 2008 & 270 & European & No details given & Not reported & Abstract & Stage 1 to 3 & 41 & $\mathrm{GP} \times 3$ & 0.63 (0.46 to 0.87 ) \\
\hline Felip et al. & 26 & 2000 to 2007 & 2010 & $409^{b}$ & European & No details given & Not reported & Full text & Stage 1 to 3 & 52 & $P C \times 3$ & 0.96 (0.84 to 1.10$)$ \\
\hline
\end{tabular}

a Hazard ratio for mortality.

${ }^{\mathrm{b}}$ Number of cases in surgery only, and neoadjuvant chemotherapy arms; excludes patients in the adjuvant chemotherapy arm.

$\mathrm{BAI}=$ bronchial artery infusion; $\mathrm{CAP}=$ cyclophosphamide, adriamycin, cisplatin; $C E P=$ etoposide, cyclophosphamide, cisplatin; $D C=$ docetaxel, carboplatin; $E P=$ etoposide, cisplatin; $G P=$ gemcitabine, cisplatin;

$M A P=$ mitomycin, adriamycin, cisplatin; $M I P=$ mitomycin, ifosfamide, cisplatin; $M V P=$ mitomycin, vindesine, cisplatin; $N P=$ navelbine, cisplatin; $P C=$ paclitaxel, carboplatin; $T N=$ paclitaxel, navelbine; $V C P=$ vindesine, cyclophosphamide, cisplatin; VIP = vindesine, ifosfamide, cisplatin; VP = vindesine, cisplatin. 
Table 2 Factors associated with benefit from neoadjuvant chemotherapy in non-small-cell lung cancer

\begin{tabular}{|c|c|c|c|c|c|c|}
\hline \multirow[t]{2}{*}{ Factors } & \multicolumn{2}{|l|}{ All trials } & \multicolumn{2}{|c|}{ Stage 1 to 3 (mixed-stage trials) } & \multicolumn{2}{|l|}{ Stage 3} \\
\hline & $\mathrm{B}(95 \% \mathrm{Cl})^{\mathrm{a}}$ & $P$ value & $\mathrm{B}(95 \% \mathrm{Cl})$ & $P$ value & $\mathrm{B}(95 \% \mathrm{Cl})$ & $P$ value \\
\hline \multicolumn{7}{|l|}{ Disease characteristics } \\
\hline Histology (squamous cell fraction) & $-0.00(-0.01$ to 0.00$)$ & 0.600 & $0.00(-0.01$ to 0.01$)$ & 0.536 & $-0.00(-0.01$ to 0.00$)$ & 0.261 \\
\hline Stage ( 1 to 3 vs 3 only) & $-0.06(-0.17$ to 0.05$)$ & 0.256 & $N R^{b}$ & $N R^{b}$ & $N R^{b}$ & $N R^{b}$ \\
\hline \multicolumn{7}{|l|}{ Treatment characteristics } \\
\hline $\begin{array}{l}\text { Platinum type (carboplatin } \\
\text { vs cisplatin based) }\end{array}$ & $-0.07(-0.15$ to 0.04$)$ & 0.205 & $-0.05(-0.18$ to 0.09$)$ & 0.411 & $N R^{c}$ & $N R^{c}$ \\
\hline $\begin{array}{l}\text { Generation of drugs } \\
\text { (older vs third-generation } \\
\text { agent protocol) }\end{array}$ & $-0.03(-0.09$ to 0.14$)$ & 0.639 & $-0.04(-0.19$ to 0.11$)$ & 0.572 & $-0.09(-0.16$ to 0.34$)$ & 0.373 \\
\hline $\begin{array}{l}\text { Number of drugs ( } 2 \text { vs } 2 \\
\text { to } 3 \text { vs } 3 \text { drugs) }\end{array}$ & $-0.01(-0.09$ to 0.06$)$ & 0.695 & $-0.03(-0.04$ to 0.11$)$ & 0.303 & $-0.18(-0.27$ to -0.08$)$ & 0.006 \\
\hline Number of chemotherapy cycles & $0.00(-0.09$ to 0.10$)$ & 0.955 & $-0.04(-0.19$ to 0.11$)$ & 0.572 & $-0.01(-0.23$ to 0.21$)$ & 0.871 \\
\hline \multicolumn{7}{|l|}{ Trial characteristics } \\
\hline Trial size ${ }^{d}$ & $0.00(-0.01$ to 0.01$)$ & 0.569 & $-0.00(-0.02$ to 0.01$)$ & 0.530 & $0.01(-0.02$ to 0.03$)$ & 0.514 \\
\hline Publication year & $0.01(-0.01$ to 0.02$)$ & 0.605 & $-0.00(-0.02$ to 0.01$)$ & 0.535 & $0.03(-0.03$ to 0.09$)$ & 0.215 \\
\hline $\begin{array}{l}\text { Origin of study (European vs } \\
\text { Asian vs US) }\end{array}$ & $-0.01(-0.10$ to 0.08$)$ & 0.885 & $0.03(-0.09$ to 0.15$)$ & 0.566 & $0.03(-0.03$ to 0.34$)$ & 0.841 \\
\hline Trial quality score ${ }^{e}$ & $0.03(-0.04$ to 0.09$)$ & 0.373 & $0.04(-0.03$ to 0.10$)$ & 0.186 & $0.12(-0.16$ to 0.40$)$ & 0.300 \\
\hline
\end{tabular}

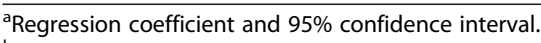

${ }^{\mathrm{b}}$ Not relevant.

'Analysis not performed due to insufficient number of trials in that subgroup.

${ }^{\mathrm{d} S}$ Square root transformation. For analyses for trial size, analyses have not been weighed for trial size.

e Over a scale from 0 to 3, depending on randomization method (details given vs not given), stratification criteria (reported vs not reported) and trial type (reported in full text or abstract).

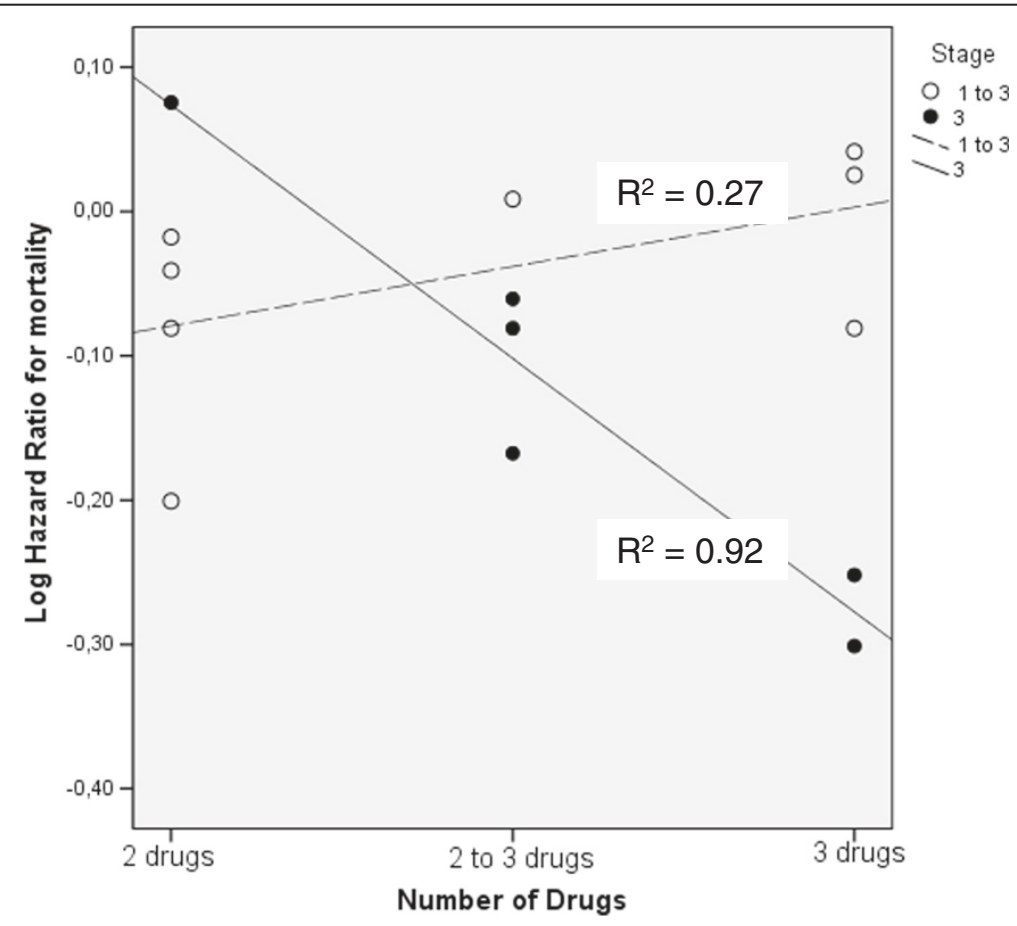

Figure 1 Number of drugs in the neoadjuvant protocol and risk of death with respect to stage of non-small-cell lung cancer. This figure shows the activity of different numbers of chemotherapy drugs in the neoadjuvant chemotherapy protocol in different stages of disease. 
these future trials of distant disease as well as of mediastinum before and after NCT, with positron emission tomography-computed tomography (PET-CT), other imaging modalities, and invasive and non-invasive means of pathological mediastinal evaluation better helping to properly quantify the amount of benefit from these protocols.

Obviously, predictive biomarker studies integrated within NCT trials are also of great importance, as some potential predictive markers have been shown to be of use in metastatic NSCLC. ERCC1 and RRM1 are two such markers that have been linked with the benefit of cisplatin and gemcitabin based protocols, respectively $[29,30]$. We think integrating different biomarkers and genomic profiling in treatment protocols of stage 3 NSCLC is also very important, since the disease biology and available treatment options in this setting are heterogeneous and each patient should be carefully evaluated on an individual basis to tailor the best treatment.

A limitation of this study is the long time period from which the trials included in the study were collected (from 1990 to 2010). Staging techniques and treatment protocols may have changed during this period of time; therefore one has to be aware of this fact when making comparisons between different studies. Particularly, integration of PET/CT into staging investigations has considerably changed routine clinical practice for patients with NSCLC, and future neoadjuvant studies have to make good use of invasive and non-invasive methods of staging, accordingly.

In a previous study, our group had investigated the correlates of benefit from neoadjuvant chemotherapy before radiotherapy in NSCLC; our current attempt extends this effort to the benefit of NCT before surgery [31]. Because personalizing treatment in stage 3 disease would also require various predictive markers in the context of different treatment settings, just as in stage 4 disease, predictive markers that are of proven benefit will be readily welcomed by thoracic oncologists.

It is interesting that in our analysis, the benefit from NCT was not different with respect to the stage of disease. In addition, an indirect methodology meta-analysis had shown that NCT was similar to adjuvant chemotherapy in terms of survival benefit provided [32]. These findings taken together suggest that when chemotherapy is indicated in stage 2 or 3 disease, NCT or adjuvant chemotherapy are reasonable options in suitable patients. It may be NCT is more beneficial for patients with borderline performance status before surgery, as performance may be expected to decline further after surgery in some patients, making adjuvant chemotherapy harder to administer [6].

In short, this literature-based analysis suggests that NCT with protocols containing three drugs is more beneficial in stage 3 NSCLC than protocols with a lesser number of agents. An individual patient data metaanalysis testing this hypothesis is eagerly awaited; also, RCTs with third-generation drugs and three agents for NCT should be conducted separately for stage 3 disease.

\section{Conclusions}

In this analysis of 14 RCTs of neoadjuvant chemotherapy before surgery, we show that in the setting of stage 3 NSCLC inclusion of 3 chemotherapy drugs in the treatment protocol is associated with less mortality. An individual patient data meta-analysis, as well as new RCTs, are needed to comment further on this issue.

\section{Competing interests}

This work had no specific funding. The authors declare that they have no conflict of interest.

\section{Authors' contributions}

HB planned, designed and analyzed the study, collected data and wrote the manuscript, HA collected data, designed the study, SC helped writing the manuscript. All authors read and approved the final manuscript.

\section{Authors' information}

A complete list of the members of the Lung Cancer Committee is given at the end of the manuscript, in the acknowledgements section.

\section{Acknowledgements}

The authors thank the Lung Cancer Committee of Turkish Oncology Group for providing valuable feedback on this paper during various group meetings. List of the members of the Lung Cancer Committee of Turkish Oncology Group (excluding the authors); Adnan Aydıner, Ahmet Çinkaya, Ahmet Demirkazık, Ahmet Özet, Ahmet Yolcu, Arzu Balkan, Ayhan Çavdar, Ayşegül Üçüncü Kefeli, Başak Oyan Uluç, Beste Atasoy, Binnaz Demirkan, Bülent Yalçın, Celalettin Eroğlu, Deniz Yalman, Diclehan Kılıç, Didem Tunalı, Dinçer Fırat, E. Selçuk Seber, Emel Üçgül Çavuşoğlu, Engin Ulukaya, Esra Kaytan Sağlam, Evrim Tezcanlı, Ezgi Eryılmaz, Fazilet Öner Dinçbaş, Ferhat Telli, Fulden Yumuk, Gül Başaran, Hale Başak Çağlar, Halil Sönmez, Hasan Yılmaz, Hüseyin Engin, Kaan Helvacı, Kemal Sönmez, Lokman Koral, Mehmet Artaç, Mehmet Fuat Eren, Muharrem Koçar, Murat Beyzadeoğlu, Mustafa Akın, Mustafa Benekli, Mustafa Cengiz, Mustafa Erman, Mustafa Yıldız,Mutlu Doğan, Müjdat Balkan, Nil Eraktuğ, Olçun Ümit Ünal, Orhan Şencan, Ö. Petek Erpolat, Pınar Saip, Sadettin Kılıçkap, Sait Okkan Selçuk Seber, Semra Paydaş, Süreyya Sarıhan, Şeref Kömürcü, Taciser Demirkasımoğlu, Taner Korkmaz, Tarkan Yetişyiğit, Tuğba Yavuzşen, Türkkan Evrensel, Tülay Akman, Ufuk Abacıoğlu, Umut Kefeli, Ünal Egeli, Yeşim Elgin, Yusuf Baran, Zeynep Bulut.

\section{Author details}

'Akdeniz University Hospital, Dept. of Medical Oncology, Antalya, Turkey.

${ }^{2}$ Adana Başkent Hospital, Dept. of Medical Oncology, Adana, Turkey.

Received: 18 March 2012 Accepted: 16 July 2012

Published: 9 August 2012

\section{References}

1. SEER: SEER Stat Fact Sheets: Lung and Bronchus: http://seer.cancer.gov/ statfacts/html/lungb.html.

2. NCCN: NCCN Clinical Practice Guidelines in Oncology. Non-Small Cell Lung Cancer, version 3 2011. http://www.nccn.com

3. Crinò L, Weder W, van Meerbeeck J, Felip E, on behalf of the ESMO Guidelines Working Group: Early stage and locally advanced (nonmetastatic) non-small-cell lung cancer: ESMO Clinical Practice Guidelines for diagnosis, treatment and follow-up. Ann Oncol 2010, 21(Suppl 5): 103-115.

4. Burdett $S$, Stewart L, Rydzewska L: A systematic review and meta-analysis of the literature: chemotherapy and surgery verus surgery alone in nonsmall cell lung cancer. J Thorac Oncol 2006, 1:611-621. 
5. Berghmans $T$, Paesmans M, Meert AP, Mascaux C, Lothaire P, Lafitte JJ, Sculier JP: Survival improvement in resectable non-small cell lung cancer with (neo)adjuvant chemotherapy: results of a metaanalysis of the literature. Lung Cancer 2005, 49:13-23.

6. Gilligan D, Nicolson M, Smith I, Groen H, Dalesio O, Goldstraw P, Hatton M, Hopwood P, Manegold C, Schramel F, Smit H, van Meerbeeck J, Nankivell M, Parmar M, Pugh C, Stephens R: Preoperative chemotherapy in patients with resectable non-small cell lung cancer: results of the MRC LU22/ NVALT 2/EORTC 08012 multicentre randomised trial and update of systematic review. Lancet 2007, 369:1929-1937.

7. Song WA, Zhou NK, Wang W, Chu XY, Liang CY, Tian XD, Guo JT, Liu X, Liu $Y$, Dai WM: Survival benefit of neoadjuvant chemotherapy in non-small cell lung cancer. An updated meta-analysis of 13 randomized control trials, J Thorac Oncol. 5th edition.; 2010:510-516.

8. Burdett S, Rydzewska LH, Tierney JF, Pignon JP: Pre-operative chemotherapy improves survival and reduces recurrence in operable non-small cell lung cancer: preliminary results of a systematic review and meta-analysis of individual patient data from 13 randomised trials. J Thor Oncol 2011, 6(Suppl 2):374-375.

9. Bristow RE, Tomacruz RS, Armstrong DK, Trimble EL, Montz FJ: Survival effect of maximal cytoreductive surgery for advanced ovarian carcinoma during the platinum era: a meta-analysis. J Clin Oncol 2002, 20:1248-1259.

10. Dautzenberg B, Benichou J, Allard P, Lebeau B, Coetmeur D, Brechot JM, Postal MJ, Chastang C: Failure of the perioperative PCV neoadjuvant polychemotherapy in resectable bronchogenic nonsmall cell carcinoma. Results from a randomized phase II trial. Cancer 1990, 65:2435-2441.

11. Rosell R, Gómez-Codina J, Camps C, Maestre J, Padille J, Cantó A, Mate JL, Li S, Roig J, Olazábal A, Canela M, Ariza A, Skacel Z, Morera-Prat J, Abad A: A randomized trial comparing preoperative chemotherapy plus surgery with surgery alone in patients with non-small-cell lung cancer. $N$ Engl $J$ Med 1994, 330:153-158.

12. Rosell R, Gómez-Codina J, Camps C, Javier Sánchez J, Maestre J, Padilla J, Cantó A, Abad A, Roig J: Preresectional chemotherapy in stage IIIA nonsmall-cell lung cancer: a 7-year assessment of a randomized controlled trial. Lung Cancer 1999, 26:7-14.

13. Roth JA, Fossella F, Komaki R, Ryan MB, Putnam JB Jr, Lee JS, Dhingra H, De Caro L, Chasen M, McGavran M, Neely Atkinson E, Hong WK: A randomized trial comparing perioperative chemotherapy and surgery with surgery alone in resectable stage IIIA non-small-cell lung cancer. J Natl Cancer Inst 1994, 86:673-680.

14. Roth JA, Atkinson EN, Fossella F, Komaki R, Bernadette Ryan M, Putnam JB $J r$, Lee JS, Dhingra H, De Caro L, Chasen M, Hong WK: Long-term follow-up of patients enrolled in a randomized trial comparing perioperative chemotherapy and surgery with surgery alone in resectable stage IIIA non-small-cell lung cancer. Lung Cancer 1998, 21:1-6.

15. Depierre A, Milleron B, Moro-Sibilot D, Chevret S, Quoix E, Lebeau B, Braun D, Breton JL, Lemarié E, Gouva S, Paillot N, Bréchot JM, Janicot H, Lebas FX, Terrioux P, Clavier J, Foucher P, Monchâtre M, Coëtmeur D, Level MC, Leclerc P, Blanchon F, Rodier JM, Thiberville L, Villeneuve A, Westeel V, Chastang C, French Thoracic Cooperative Group: Preoperative chemotherapy followed by surgery compared with primary surgery in resectable stage I (except T1N0), II, and Illa non-small-cell lung cancer. $J$ Clin Oncol 2002, 20:247-253.

16. Nagai K, Tsuchiya R, Mori T, Tada H, Ichinose Y, Koike T, Kato H, Lung Cancer Surgical Study Group of the Japan Clinical Oncology Group: A randomized trial comparing induction chemotherapy followed by surgery with surgery alone for patients with stage IIIA N2 non-small cell lung cancer (JCOG 9209). J Thorac Cardiovasc Surg 2003, 125:254-260.

17. Sorensen HR, Ravn J, Hansen O, Palshof T, Rytter C, Mattson K, Ladegaard L, Pilegaard $\mathrm{H}$, Aaseboe U: Scandinavian phase III trial of neoadjuvant chemotherapy in NSCLC stages IB-IIIA/T3. J Clin Oncol 2005, 23:LAB7146.

18. Pisters K, Vallieres E, Bunn P, Crowley J, Ginsberg R, Ellis P, Meyers B, Marks R, Treat J, Gandara D, Southwest Oncology Group: A phase III trial of surgery alone or surgery plus pre-operative (pre-op) paclitaxel/ carboplatin $(\mathrm{PC})$ chemotherapy in early stage non-small cell lung cancer (NSCLC): preliminary results. Proc Am Soc Clin Oncol 2006, 24:LBA7012.

19. Pisters K, Vallieres E, Bunn PA, Crowley J, Chansky K, Ginsberg R, Gandara DR, Southwest Oncology Group: Southwest Oncology Group. S9900: Surgery alone or surgery plus induction (ing) paclitaxel/carboplatin (PC) chemotherapy in early stage non-small cell lung cancer (NSCLC): followup on a phase III trial. J Clin Oncol 2007, 25:LAB7520.

20. Scagliotti GV, Pastorino U, Vansteenkiste JF, Spaggiari L, Facciolo F, Orlowski T, Maiorino A, Hetzel M, Visseren-Grul C, Torri V: A phase III randomized study of surgery alone or surgery plus preoperative gemcitabinecisplatin in early-stage non-small cell lung cancer (NSCLC): Follow-up data of Ch. E.S.T. J Clin Oncol 2008, 26:LAB7508.

21. Zhou Q, Liu L, Li L, Che G, Yang J, Zhao Y, Chen J, Wang Y, Qin J, Hou M, Gong Y, Lu W, Li Z: A randomized clinical trial of preoperative neoadjuvant chemotherapy followed by surgery in the treatment of stage III non-small cell lung cancer [in Chinese]. Chin J Lung Cancer 2001, 4:251-256.

22. Liao ML, Zhou YZ, Ding JA, Ni GX, Zhao JM, Chen WH, Han BH, Shen J, Bai $H$, Chen ZW, Ji H, Wang HM, Zhou Z: The study of peri-operative chemotherapy in stage I-Illa NSCLC [in Chinese]. Zhonghua Yi Xue Za Zhi 2003, 83:962-966.

23. Zhou Q, Liu L, Li L, Che G, Yang J, Zhao Y, Chen J, Wang Y, Qin J, Hou M, Gong Y, Lu W, Li Z: A randomized clinical trial of preoperative neoadjuvant chemotherapy in the treatment of stage III non-small cell lung cancer [in Chinese]. J Clin Oncol China 2004, 31:611-613.

24. Li Q, Song $Y H$, Zheng $Z Y$, et al: Clinical evaluation of preoperative short course chemotherapy in treatment of stage III non-small cell lung cancer. Chin J Cancer Prev Treat 2005, 10:505-507.

25. Scagliotti GV, on behalf of Ch.E.S.T. Investigators: Preliminary results of $\mathrm{Ch}$. E.S.T.: a phase III study of surgery alone or surgery plus pre-operative gemcitabine-cisplatin in clinical early stages non-small cell lung cancer (NSCLC). Proc Am Soc Clin Oncol 2006, 23:LBA7023.

26. Felip E, Rosell R, Maestre JA, Rodríguez-Paniagua JM, Morán T, Astudillo J, Alonso G, Borro JM, González-Larriba JL, Torres A, Camps C, Guijarro R, Isla D, Aguiló R, Alberola V, Padilla J, Sánchez-Palencia A, Sánchez JJ, Hermosilla E, Massuti B, Spanish Lung Cancer Group: Preoperative chemotherapy plus surgery versus surgery plus adjuvant chemotherapy versus surgery alone in early-stage non-small cell lung cancer. J Clin Oncol 2010, 28:3138-3145.

27. Esteban E, de Sande JL, Villanueva N, Corral N, Muñiz I, Vieitez JM, Fra J, Fernández Y, Estrada E, Fernandez JL, Luque M, Jimenez P, Mareque B, Capellan M, Buesa JM, Lacave AJ: Cisplatin plus gemcitabine with or without vinorelbine as induction chemotherapy prior to radical locoregional treatment for patients with stage III non-small-cell lung cancer (NSCLC): results of a prospective randomized study. Lung Cancer 2007, 55:173-180.

28. Schallier D, Neyns B, Fontaine C, Steene JV, De Mey J, Meysman M, De Grève J: A novel triplet regimen with paclitaxel, carboplatin and gemcitabine (PACCAGE) as induction chemotherapy for locally advanced unresectable non small cell lung cancer (NSCLC). Lung Cancer 2007, 56:247-254.

29. Craig R, Coleman O, Michael J: Schell randomized phase III trial of gemcitabine-based chemotherapy with in situ RRM1 and ERCC1 protein levels for response prediction in non-small-cell lung cancer. J Clin Oncol, 27:5808-5815.

30. Simon GR, Ismail-Khan R, Bepler G: Nuclear excision repair-based personalized therapy for nonsmall cell lung cancer: from hypothesis to reality. Int J Biochem Cell Biol 2007, 39:1318-1328.

31. Bozcuk H, Artac M, Ozdogan M: Correlates of benefit from neoadjuvant chemotherapy before radiotherapy in non-small cell lung cancer: a meta-analytical approach with meta-regression analysis. J BUON 2010, 15:43-50.

32. Lim E, Harris G, Patel A, Adachi I, Edmonds L, Song F: Preoperative versus postoperative chemotherapy in patients with resectable non-small cell lung cancer systematic review and indirect comparison meta-analysis of randomized trials. Thorac Oncol 2009, 4:1380-1388.

doi:10.1186/1477-7819-10-161

Cite this article as: Bozcuk et al: The correlates of benefit from neoadjuvant chemotherapy before surgery in non-small-cell lung cancer: a metaregression analysis. World Journal of Surgical Oncology 2012 $10: 161$ 